Reprod. Nutr. Dévelop., 1982, 22 (1 A), 135-151.

\title{
Immunocytological study of the chronology of pituitary cytogenesis in the domestic pig (Sus scrofa) with special reference to the functioning of the hypothalamo-pituitary-gonadal axis
}

\author{
E. DANCHIN, M. P. DUBOIS $\left(^{*}\right)$
}

Laboratoire d'Anatomie, 45, rue des Saints-Pères, 75270 Paris Cedex 06 and Laboratoire de Physiologie de la Reproduction, Université Paris VI, INRA, 78350 Jouy-en-Josas.

(*) Station de Physiologie de la Reproduction, INRA Nouzilly, 37380 Monnaie, France.

Summary. This paper reports an immunofluorescent study of the pituitary in the fetal pig (Sus scrofal. Fifteen antisera were used against most of the hormones present in the pituitary. Five types of hypophysial endocrine cells were observed in the anterior and intermediate lobes. We determined the sequential appearance of these various cell types in the fetus. The first hormones found at 33 days were ACTH, $\beta-\mathrm{MSH}, \beta-$ and $\gamma-\mathrm{LPH}$ and $\alpha$ and $\beta$-endorphin ; $\alpha$-MSH appeared at 40 days and STH at 45 days. The glycoprotein hormones, LH ( 45 days), TSH (50 days) and FSH ( 60 days), appeared between 45 and 60 days. The density and staining of the gonadotropes increased up to 80 days, at which time they reached values similar to those of the adult. Prolactin was not found until 80 days.

An anti-LHRH antiserum was used to study LHRH neuron differentiation between 30 and 70 days of pregnancy. The first immunoreactive perikaryons were found at 40 days but the immunoreactive fibers did not reach the median eminence until about 60 days. However, we observed differentiated capillary loops in the palisade layer of the median eminence only in the 70-day fetus.

These results when compared with actual data on the differentiation of the reproductive function in the pig fetus permitted us to define an overall pattern of the differentiation and functioning of the fetal neuroendocrine hypothalamo-pituitary-gonadal system in the porcine species. This pattern includes (i) autodifferentiation and autofunctioning of the gonads and (ii) autodifferentiation of the pituitary with (iii) later assumption by the hypothalamus followed by a phase during which the whole reproductive system functions.

\section{Introduction.}

Since the early 1960's, fluorescein-labeled antibodies have been used in mammalian pituitary to identify five different cell types which can be distinguished by the hormones found in their cytoplasm. Moreover, these techniques permit early detection of the endocrine cells in the hypophysial primordia during fetal development, when the levels of synthesized hormones are still too low to be detected by cytochemical methods. 
LHRH-containing fibers (Leonardelli et al., 1973) and then immunoreactive perikaryons (Barry et al., 1973) were identified by anti-LHRH in the hypothalamus and median eminence of guinea-pig. These results, at first highly contested, were finally confirmed in the same species by other authors (Silverman, 1976 ; Setalo et al., 1976a ; Hoffman et al., 1978 ; Weindl and Sofroniew, 1978).

Since then anti-LHRH-reacting perikaryons have been identified in many species (see Barry, 1979) ; some authors have tried to find them in fetuses (mice : Gross and Baker, 1979; guinea-pigs; Barry and Dubois, 1974b ; humans : Bugnon et al., 1976a, 1978 ; Paulin et al., 1977).

Not only has the time of appearance of these cell types been studied, but some work has also been done on their functional differentiation. Gross and Baker (1979) found a close temporal relationship between the appearance of $\mathrm{GnRH}$ and $\mathrm{LH}$ in mice. These data suggest the existence of a functional hypothalamo-pituitary axis at the end of fetal development. On the other hand, Paulin et al. (1977) studying humans, concluded that the hypothalamus does not influence the differentiation of gonadotropes during gestation but that it could be responsible for functional variations in the LH activity of those cells. This contradiction arose because two different processes, more or less separated in time - (i) the cytological differentiation of gonadotropes and (ii) their complete functional maturation - must be distinguished.

\section{Material and methods.}

1. Pituitary. - Twenty pituitaries were taken from pig fetuses ranging in age from 30 (day 0 was the day heat appeared) to 112 days, parturition occurring regularly at 114 days (table 1 ).

2. Hypothalamus. - We used 8 fetal hypothalami (table 2).

TABLE 1

Age and sex of fetuses used to study the pituitary

\begin{tabular}{|c|c|c|c|c|c|c|c|c|c|c|}
\hline Age (days) & 30 & 30 & 33 & 37 & 40 & 40 & 45 & 45 & 50 & 50 \\
\hline Sex & $\sigma^{*}$ & q & $q$ & $q$ & q & 9 & 우 & q & q & $\sigma^{\prime}$ \\
\hline Age (days) & 50 & 55 & 60 & 60 & 70 & 80 & 90 & 100 & 110 & 112 \\
\hline Sex $\ldots .$. & $\sigma^{\prime}$ & $\sigma$ & $q$ & ९ & or & $\sigma$ & $\%$ & o & o & $\sigma^{\prime}$ \\
\hline
\end{tabular}

TABLE 2

Age and sex of fetuses used to study the hypothalamus

\begin{tabular}{llcccccccc}
\hline Age (days) $\ldots \ldots \ldots \ldots \ldots \ldots \ldots \ldots \ldots \ldots$ & 30 & 33 & 37 & 40 & 45 & 50 & 60 & 70 \\
\hline Sex $\ldots \ldots \ldots \ldots \ldots \ldots \ldots \ldots \ldots \ldots \ldots \ldots$ & $\wp$ & $\wp$ & $\circ$ & $\wp$ & $\wp$ & $\circ$ & $\wp$ & $\sigma^{*}$ \\
\hline
\end{tabular}


3. Fixation. - After washing the vascular layer with heparinized physiological serum, the 30 to 60 -day old fetuses were fixed by intracardiac perfusion with sublimate Bouin-Hollande without acetic acid for $5 \mathrm{~min}$. The 70 to 112-day fetuses were perfused through both carotids simultaneously. After dissection, the sampled organs were immersed in the same fixative for 7 days.

4. Sex. - After dissection, we determined the sex of the 30 to 40-day fetuses by morphological observation of the gonad; the sex of fetuses $\mathbf{4 5}$ days or older was determined by examination of the external genitals.

5. Antibodies and immunofluorescence. - After the pituitaries, embedded in paraffin and cut into 5 - $\mu$ thick sections, had been mounted with gelatinous water $(0.5 \mathrm{p} .100)$ they were treated by indirect immunofluorescence using immune sera $(1 / 200$ for $3 \mathrm{~h})$ against the gonadotropins or their $\beta$ subunit $(\mathrm{LH}, \mathrm{FSH}, \beta-\mathrm{LH}$, $\beta$-FSH $\left({ }^{*}\right)$, the $\beta$ unit of thyrotropin $\beta$-TSH), prolactin (PRL), somatotropin (STH), corticotropin (ACTH (1-24) and (17-39)), melanotropins ( $\alpha$ - and $\beta$-MSH), lipotropins ( $\beta$ - and $\gamma$-LPH) and $\alpha$ - and $\beta$-endorphins.

An anti-LHRH antibody was used $(1 / 100$ for $3 \mathrm{~h})$ for the hypothalami. Table 3 regroups the antigenic sources used to obtain the antisera. The antigammaglobulin antibodies of rabbit, raised in sheep, were provided by the Institut Pasteur (Paris).

TABLE 3

Antigenic sources used in preparing the antisera

\begin{tabular}{|c|c|}
\hline Antigen & Source and reference \\
\hline 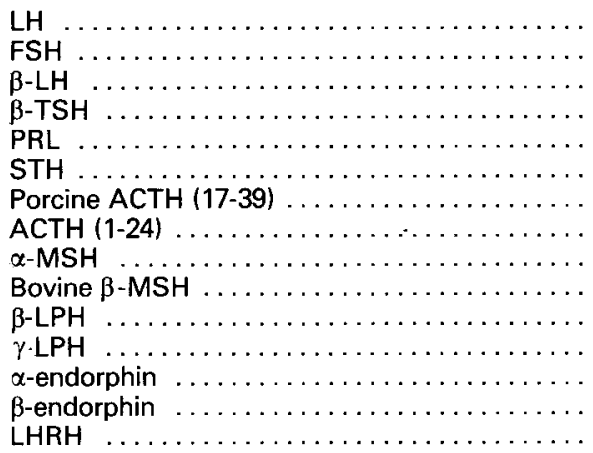 & $\begin{array}{l}\text { Ovine (CNRS, } \mathrm{M}_{2} \text { ) } \\
\text { Ovine (CNRS, M } \\
\text { Porcine (Dr. Courte, INRA) } \\
\text { Bovine (antisérum : Dr. Pierce, Los Angeles) } \\
\text { Bovine (NIH, PB }{ }_{2} \text { ) } \\
\text { Human (Kabi, Stockholm) } \\
\text { Synthetic (Ciba-Geigy, Bâle) } \\
\text { Synthetic (Ciba-Geigy, Bâle) } \\
\text { Synthetic (Ciba-Geigy, Bâle) } \\
\text { Synthetic (Ciba-Geigy, Bâle) } \\
\text { Porcine (Dr. Graaf, Budapest) } \\
\text { Porcine (Dr. Graaf, Budapest) } \\
\text { (Dr. Guillemin, San Diego) } \\
\text { (Dr. Guillemin, San Diego) } \\
\text { Synthetic (Cyclo Chemical Ltd, Los Angeles) }\end{array}$ \\
\hline
\end{tabular}

6. Specificity. - The specificity of the antibodies was systematically checked on the pituitaries and the hypothalami (i) by omitting the first antibody, (ii) by replacing that antibody by nonimmune rabbit serum or (iii) by previously

(*) Anti- $\beta$-FSH : HCG-saturated anti-ovine FSH $(20000 \mathrm{IU} / \mathrm{ml}$ undiluted antiserum). 
incubating the first antibody in the presence of an homologous or heterologous antigen. The specificity of these same antisera had been confirmed by studies on the pituitary in many vertebrate species (fish : Follenius and Dubois, 1978; amphibians : Moriceau-Hay et al., 1979 ; rodents : Tramu and Dubois, 1972 ; Chatelain et al., 1979 ; cattle : Dubois, 1969 ; Dacheux and Dubois, 1976 ; pigs : Dacheux, 1978, 1981 ; sheep : Dubois and Mauléon, 1969 ; primates : Girod and Dubois, 1976 ; humans : Begeot et al., 1978 ; Dubois et al., 1978) and the hypothalamus (Barry et al., 1973 ; Dubois and Barry ; 1974 ; Barry et al., 1975 ; Paulin et al., 1977 ; Tramu et al., 1977 ; review in Barry, 1979).

\section{Results.}

The different tests we carried out showed that staining specificity was satisfactory (table 4).

1. Chronology of cell appearance (table 5). - No immunopositive cells were found in 30-day pituitaries with the antisera used. The first corticotropes which appeared at 33 days were situated in the most anterior part of the pituitary and reacted to anti-ACTH (1-24) and (17-39), anti- $\beta$-MSH, $\gamma$-LPH and $\alpha$ - and $\beta$-endorphins. The same cells reacted with anti- $\beta-\mathrm{LPH}$, and some other more posterior cells were also positive (PI. I, 1, 2, 3). The intermediate lobe showed no

\section{PLATE I}

Fetal pig pituitary. Apparition of corticotropes.

1. - 33-day fetus, section treated with anti- $\beta$-LPH : anterior region of the LA is rich in immunoreactive cells. More posteriorly, cell density is lower. $(\times 130)$.

2. - 33 day fetus, adjoining section treated with anti-ACTH (17-39) : only the anterior part of the LA shows immunoreactive cells. $(\times 130)$.

3. - 33-day fetus : cells of the anterior region of the LA identified by anti- $\beta$-endorphin. $(\times 540)$.

4. - 37-day fetus: section treated with anti- $\beta$-LPH : at this time, this antibody identifies more posterior cells. $(\times 130)$.

5. - 37-day fetus, adjoining section treated with anti-ACTH (17-39) : The LI presents immuno-reactive cells occurring in smaller numbers than with anti- $\beta-\mathrm{LPH}$ antibody. $(x 130)$.

6. - 40-day fetus : first cells identified by anti- $\alpha-\mathrm{MSH}$ in the LI. $(\times 540)$.

EM : median eminence ; LA : anterior lobe of pituitary ;

LI : intermediate lobe of pituitary ; LP : posterior lobe of pituitary ;

The dashed lines outline the different lobes of the pituitary. 
TABLE 4

Immunofluorescence observed in the pituitary with immunserum previously incubated with various homologous or heterologous antigens

\begin{tabular}{|c|c|c|c|c|c|c|}
\hline \multirow[b]{2}{*}{ Antibody } & \multicolumn{6}{|c|}{ Antigens } \\
\hline & $\begin{array}{l}\text { Without } \\
\text { antigen }\end{array}$ & $\beta$-LH ov & LH ov & TSH ov & STHh & PRL ov \\
\hline$\beta$-LH por. & +1 & - & - & + & & \\
\hline LH ov $\ldots \ldots \ldots \ldots \ldots \ldots$ & $+1-11$ & +- & - & +- & & \\
\hline FSH ov $\ldots \ldots \ldots \ldots \ldots \ldots$ & $+1-11$ & + & +- & +- & & \\
\hline $\mathrm{FSH}$ ov $+\mathrm{HCG} \ldots \ldots \ldots \ldots$ & +1 & + & +- & +- & & \\
\hline$\beta$-TSH bov $\ldots \ldots \ldots \ldots \ldots \ldots$ & + II & + & + & - & & \\
\hline STH $h \ldots \ldots \ldots \ldots \ldots \ldots$ & +111 & & & & - & + \\
\hline PRL ov & $+\mathrm{IV}$ & & & & + & - \\
\hline
\end{tabular}

\begin{tabular}{|c|c|c|c|c|c|c|}
\hline \multirow[b]{2}{*}{ Antibody } & \multicolumn{6}{|c|}{ Antigens } \\
\hline & $\begin{array}{l}\text { Without } \\
\text { antigen }\end{array}$ & $\begin{array}{l}\text { ACTH } \\
(1-24)\end{array}$ & $\alpha-M S H$ & $\beta-\mathrm{MSH}$ & $\alpha$-endorphin & $\begin{array}{l}\text { ACTH } \\
(1-39)\end{array}$ \\
\hline АСТH $(17-39) \ldots \ldots \ldots \ldots$ & $+V-V I$ & + & & & & - \\
\hline ACTH (1-24) & $+V-V I$ & - & + & + & & \\
\hline$\beta-M S H \quad \ldots \ldots \ldots \ldots \ldots$ & $+V-V I$ & + & + & - & & \\
\hline$\alpha-\mathrm{MSH} \ldots \ldots \ldots \ldots \ldots$ & $+V I$ & + & - & + & & \\
\hline$\beta$-LPH $\ldots \ldots \ldots \ldots \ldots \ldots$ & $+\mathrm{V}-\mathrm{VI}$ & + & & + & + & \\
\hline$\gamma-\mathrm{LPH}$ & + VI-V & + & + & + & & \\
\hline$\alpha$-endorphin $\ldots \ldots \ldots \ldots \ldots$ & $+\mathrm{V}-\mathrm{VI}$ & + & & & - & \\
\hline$\beta$-endorphin $\ldots \ldots \ldots \ldots$ & $+V-V I$ & + & & & + & \\
\hline
\end{tabular}

+ positive reaction ; - negative reaction ; +- lower reaction than control.

I : gonadotropes ; II : thyreotropes ; III : somatotropes ; IV : prolactotropes ; V : corticotropes of the anterior lobe ; $\mathrm{VI}$ : corticotropes of the intermediate lobe.

positive cells, and anti- $\alpha$-MSH gave no positive response. At 37 days, the corticotropes of the anterior lobe responded to the seven antisera studied. Those of the intermediate lobe reacted maximally to anti- $\beta$-LPH but rather weakly to other antibodies (PI. I, 4, 5). Only very few of these cells exhibited a slight 
TABLE 5

Summary of the main stage of cytological differentiation in the fetal pig pituitary

\begin{tabular}{cl}
\hline Date (days) & \multicolumn{1}{c}{ Process observed } \\
\hline 30 & No positive labeling \\
33 & First corticotropes (anterior-posterior gradient) \\
40 & First anti- $\alpha$-MSH labeling \\
45 & First somatotropes \\
45 & First, very rare, gonadotropes \\
50 & First, very rare, thyreotropes \\
80 & Gonadotropes reach maximal level and density \\
80 & First lactotropes \\
114 & Parturition; numerous lactotropes \\
\hline
\end{tabular}

reaction to anti- $\alpha-\mathrm{MSH}$. At 40 days, the intermediate lobe cells were labeled by anti- $\alpha$-MSH (PI. 1, 6). It thus seems that the corticotropes differentiate according to an anterior-posterior gradient, the first hormone to appear being $\beta-\mathrm{LPH}$. At 45 days, very few gonadotropes and some somatotropes were revealed by $\mathrm{LH}$ and $\beta$-LH and STH, respectively; after a period of high levels between 50 and 70 days, the somatotropes were very weakly stained up to the end of pregnancy. At 50 days, the first thyrotropes appeared, and at 60 days anti-FSH and HCGsaturated FSH reacted positively on a small number of cells (PI. II, 1, 2, 3). From 60 to 80 days, the number of gonadotropes increased markedly, and from 80 days their contents and density, which seemed constant, were similar to those observed in adults. At 80 days, we observed the first lactotropes. Fetuses of 100 , 110 and 112 days showed a large number of these cells which had a high staining intensity at 110 and 112 days (PI. II, 4).

2. Hypothalamus. - The staining specificity of the anti-LHRH tested in each hypothalamus was satisfactory (PI. III, 1, 2).

Fetal hypothalami of 30,33 and 37 days showed no positive labeling. At 40 days, numerous perikaryons with variable contents were seen in the most anterior (paraolfactory and rostral precommissural) areas. Practically no immunoreactive fiber was visible at that time. At 45 days, the situation was similar but there were fewer cells.

In figure 1 showing a 50-day fetus, the situation was somewhat different. Cells were also visible in the lamina terminalis.

At 60 days (fig. 2), the distribution was different. Fewer perikaryons were visible but some were present in the rostral limbic and septal areas; one perikaryon was seen in the rostral mesencephalic area. The fibers were no longer limited to the lamina terminalis but extended towards and into the median eminence which was hardly yet vascularized (PI. III, 5).

At 70 days, cell number and content were still lower. Fibers were seen in the median eminence where the capillary loops were well differentiated in the palisade layer (PI. III, 7). 

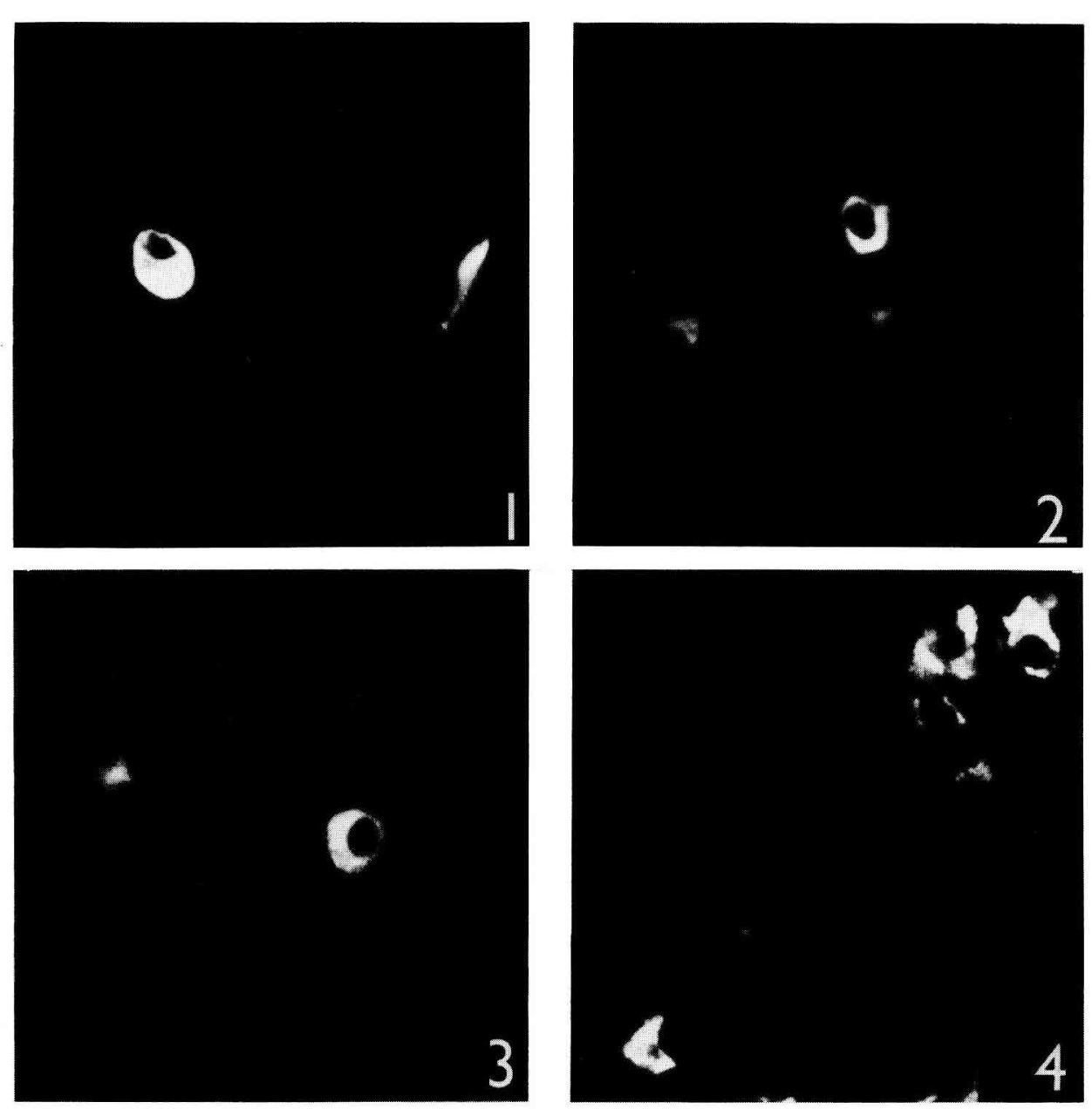

\section{PLATE II}

\section{Fetal pig pituitary,}

1. - 60-day fetal pituitary : cells identified by anti- $\beta-\mathrm{LH} .(\times 625)$,

2. - 80-day fetal pituitary : cells identified by HCG-saturated anti-FSH. $(\times 625)$.

3. -80 -day fetal pituitary c cells identified by anti- $\beta-$ TSH. $(\times 625)$.

4. - 90-day fetal pituitary : cells identified by anti-PRL. $(\times 625)$. 


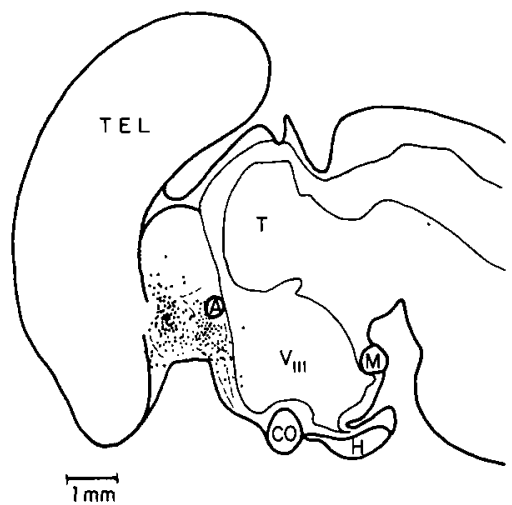

FIG. 1. - Topography of LHRH neurons at 50 days $(\times 5)$. The dashed lines are the fibers; each point represents one perikaryon (only neurons observed on 20 p. 100 of the serial sections are shown). A : anterior white commissure ; $\mathrm{CO}$ : optic chiasma ; $\mathrm{H}$ : anterior pituitary ; $\mathrm{M}$ : mamillary bodies; $T$ : thalamus ; TEL : telencephalon.

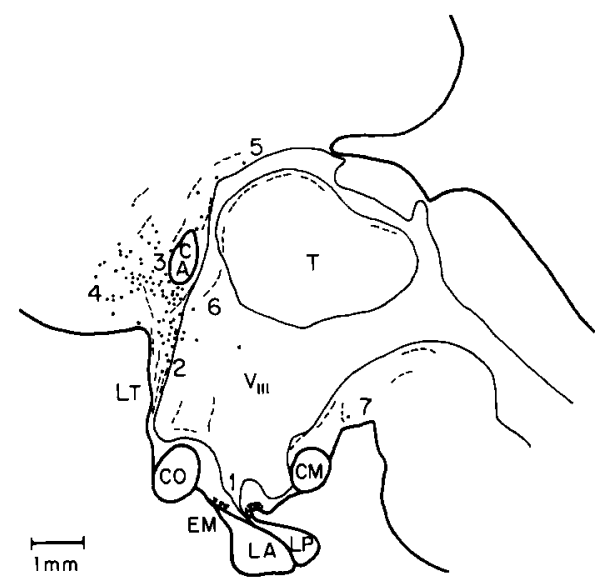

FIG. 2. - Topography of $L H R H$ neurons at 60 days $(\times 5)$. The dashed lines are fibers; each point represents one neuron lonly neurons observed on $20 \mathrm{p}$. 100 of the serial sections are shown). 1 : mediobasal hypothalamus ; 2 : preopticoterminal region ; 3 : precommissural region ; 4: paraolfactory region; 5 : rostral limbic region; 6 : septoepithalamic region ; 7 : rostral mesencephalic region. CA : anterior white commissure ; CM : mamillary body ; CO : optic chiasma ; EM : median eminence ; LA : anterior lobe of pituitary; LP : posterior lobe of pituitary; LT : lamina terminalis; $T$ : thalamus ; $V_{i l l}$ : third ventricle.

\section{Discussion.}

Fetal pituitary. - Our results on the chronology of the appearance of the various hypophysial cell types agree with those of other authors who have studied the same process (besides those already cited : Bugnon et al., 1976b, c ; Setalo and 
Nakane, 1976 ; Baker and Yu, 1977 ; Watanabe and Daikoku, 1979 ; Danchin et al., 1981). However, individual factors may play a role ; one of us (Dubois, 1977) in a previous study observed an earlier appearance (at 30 days) of corticotrope immunoreactivity.

During early differentiation of the corticotropes according to an anteroposterior gradient between 33 and 40 days we observed, as other authors, that the first immune serum labeling the cells was anti- $\beta$-LPH (Chatelain et al., 1979), while anti- $\alpha$-MSH was the last to reveal the intermediate lobe cells (Baker and Jaffe, 1975 ; Dupouy and Dubois, 1975; Bugnon et al., 1976a). These observations are compatible with the existence of a common precursor having some peptide sequences which would be inaccessible to antibodies until they had cleaved into different hormonal molecules (Mains et al., 1977 ; Chatelain et al., 1979 ; Chrétien et al., 1979 ; Hakanson et al., 1980).

The somatotropes appeared at 45 days. Their low content after 70 days might be due either to a decrease in STH synthesis, which would explain the insignificant role of the pituitary in fetal growth (Jost and Cohen, 1966 ; Jost et al., 1966 ; Stryker and Dziuk, 1975), or to increased STH release because fetal plasma assays show a strong increase of that hormone beginning at 70 days (Atinmo et al., 1976).

When the first gonadotropes appeared at 45 days and the first thyrotropes at 50 days, we did not observe any dissociation between the $\alpha$ and $\beta$ units of glycoprotein hormones as reported in humans (Dubois et al., 1975 ; Bugnon et al., 1976d).

However, a first phase of fetal gonadotrope development occurred between 45 and 70 days during which cell density increased gradually; a second phase from 80 days showed constant cell density and maximal fluorescence.

PLATE III

Fetal hypothalamus.

1. - 60-day fetus : cells and fibers identified by anti-LHRH. $(\times 210)$.

2. - Adjoining section treated with anti-LHRH previously saturated by $1 \mathrm{mg}$ of LHRH per $\mathrm{ml}$ of pure antibody. $(\times 210)$.

3. - 40-day fetus: LHRH neurons in the paraolfactory region. $(\times 390)$.

4. - 50-day fetus : LHRH neurons in the paraolfactory region. $(\times 390)$.

5. - 60-day fetus : LHRH fibers in the palisade layer of the median eminence; no capillary loop is visible. $(\times 210)$.

6. - 70-day fetus : LHRH neuron in the preoptic terminal. $(\times 390)$.

7. - 70-day fetus : well-differentiated capillary loops are visible (arrow).

CP : palisade layer ; $f$ : fiber ; $n$ : LHRH neuron; PT : pars tuberalis ;

$V_{\text {III }}$ : third ventricle. ;

The dashed lines outline the anatomical regions. 

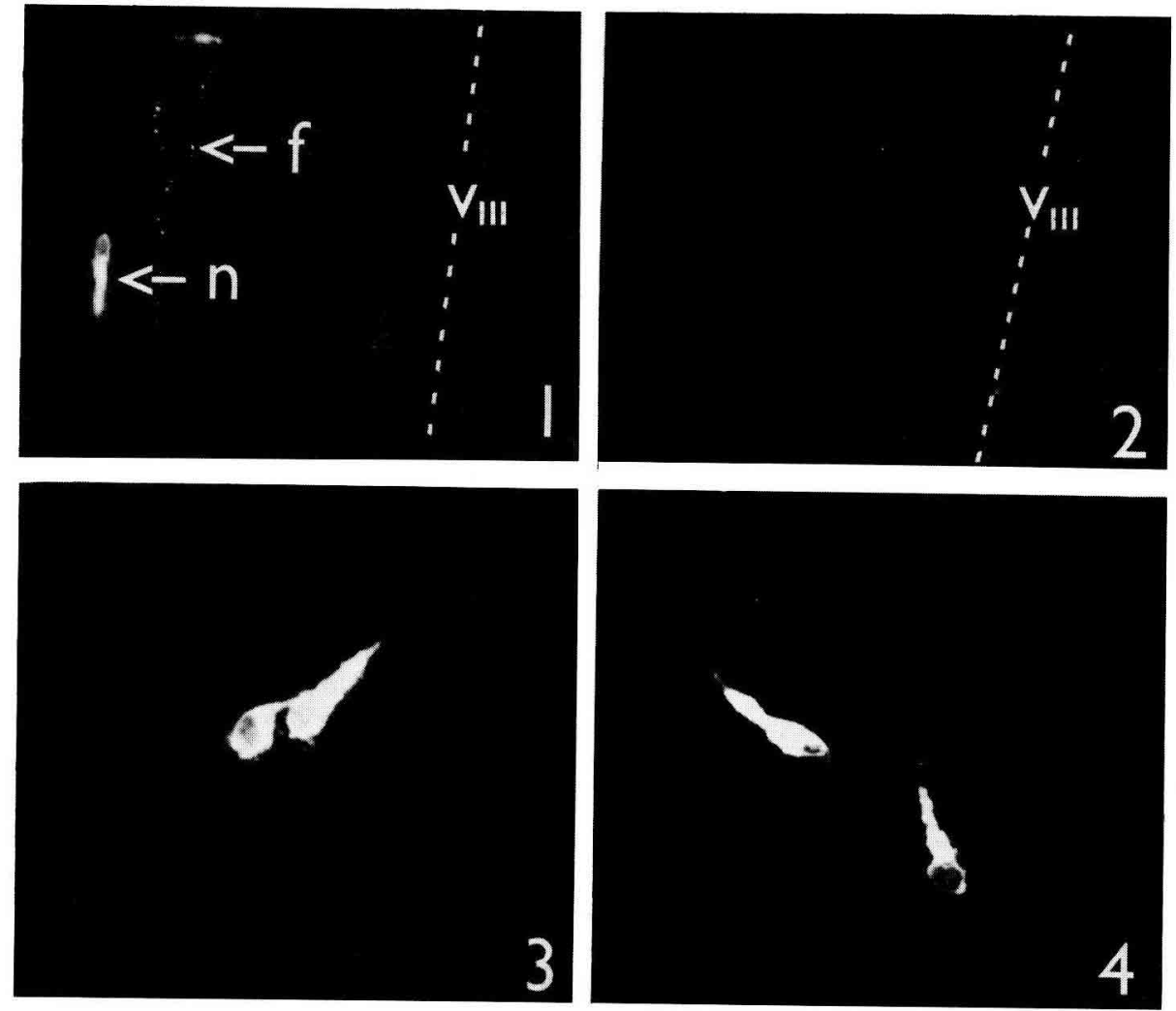

4
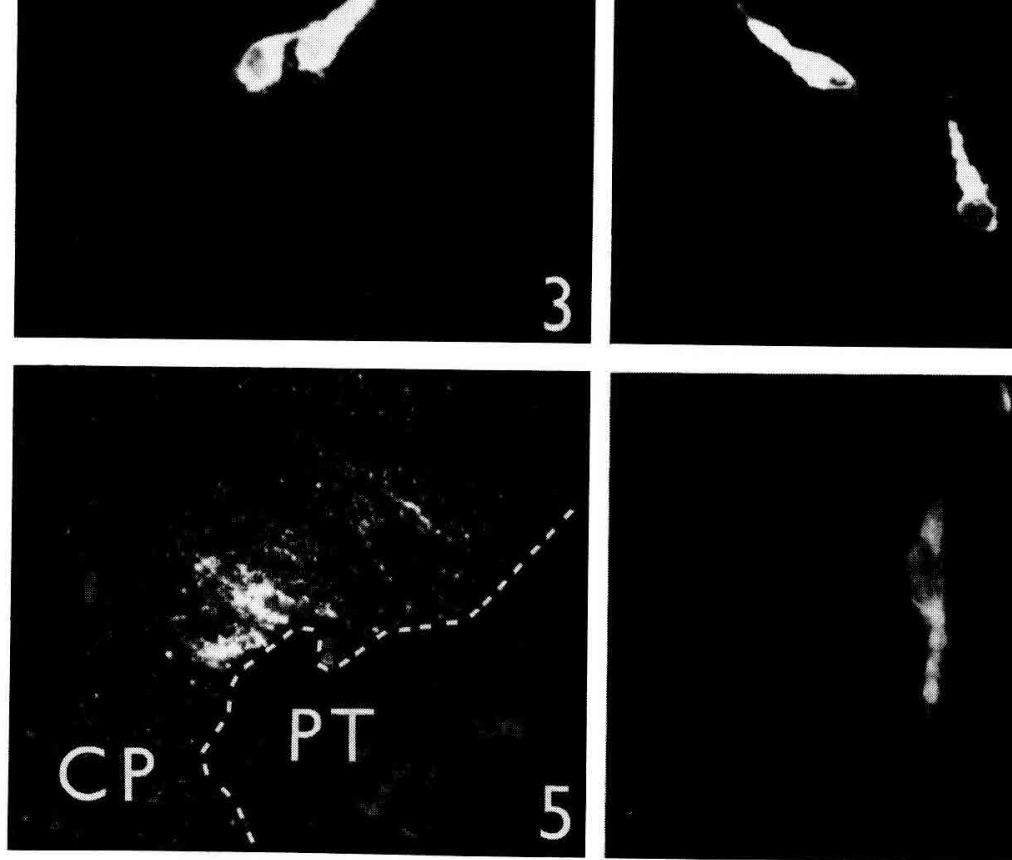

2

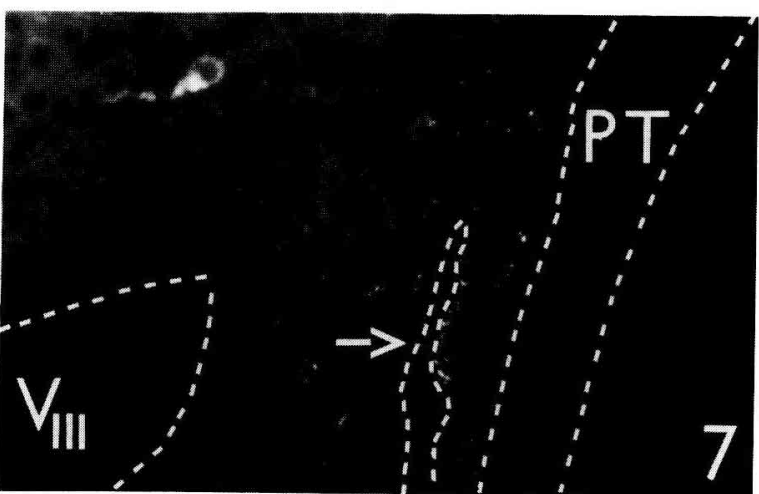

6 
According to Smith and Dortzbach (1929), Melampy et al. (1966) and Liwska (1975), 80 days is an important stage in the evolution of hypophysial LH concentrations. Also, Colenbrander et al. (1977) showed that circulating $\mathrm{LH}$, which is undetectable between 49 and 80 days, augments significantly from 80 days. Moreover, Elsaesser et al. (1976) and MacDonald (1979) measured high quantities of plasma LH during the last three weeks of pregnancy (see MacDonald, 1979).

Thus, as we also noted using immunofluorescence, the 70 to 80 -day period is an important stage in the functional differentiation of gonadotropes.

We observed prolactin cells only from 80 days, thus agreeing with the data of authors who noted that these cells always differentiate late, if not last.

Fetal hypothalamus. - Figure 2 shows a very anterior distribution of anti-LHRH immunoreactive perikaryons. This topography, very similar to that reported in guinea-pigs (Barry et al., 1973 ; Setalo et al., 1976a ; Jennes and Stumpf, 1980), cats (Barry and Dubois, 1974a, 1975) and rats (Naik, 1975a, b ; Setalo et al., 1976b ; Ibata et al., 1979), was obtained in young fetuses (60 and 70 days) and may therefore be different from adult distribution.

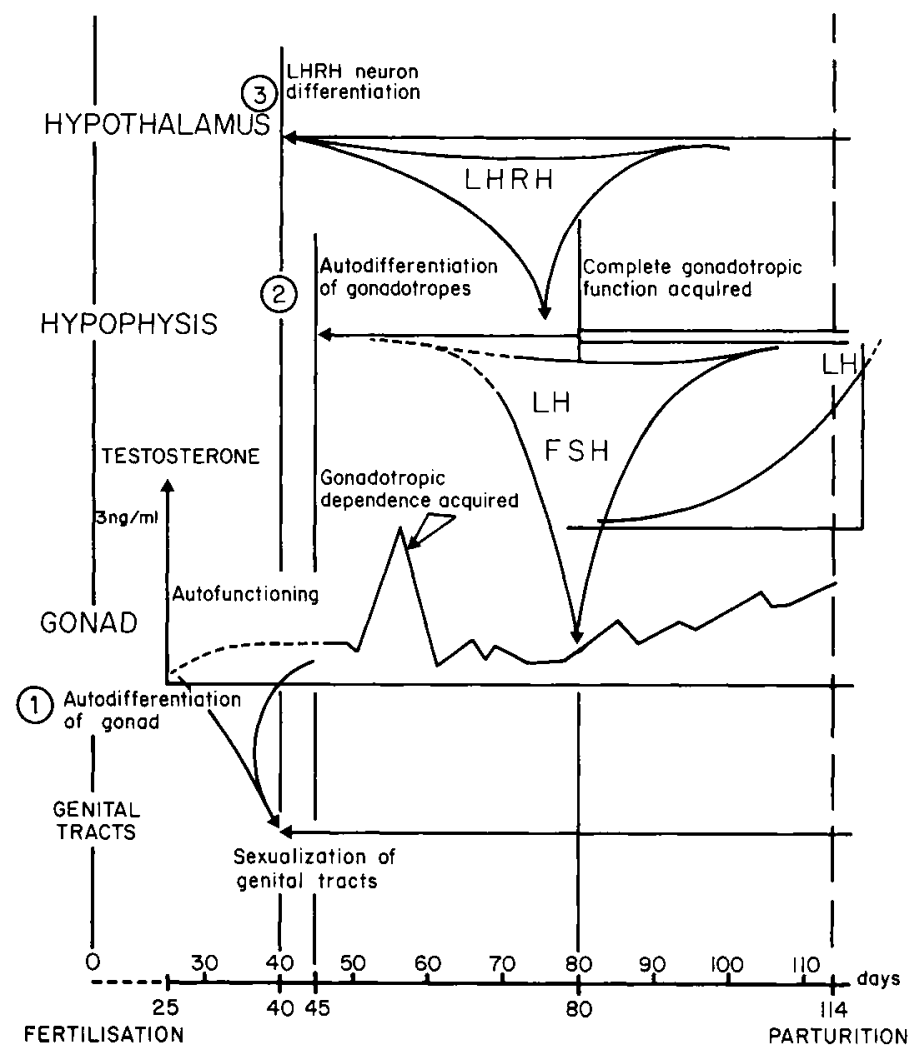

FIG. 3. - Diagram showing how the neuroendocrine hypothalamo-pituitary-gonad system is triggered in the fetal pig (Sus scrofa). 
The very precocious appearance of LHRH neurons agrees with studies in humans using either immunofluorescence (Bugnon et al., 1977a, b, 1978 ; Paulin et al., 1977) or hypothalamic LHRH assay (Winters et al., 1974). However, as in humans (Paulin et al., 1977), we noted that relations with the pituitary are only established much later, i.e. between 60 and 70 days.

Differentiation and triggering of the hypothalamo-pituitary-gonad system. - All the data obtained on the differentiation of the porcine hypothalamo-pituitarygonad system have been regrouped in figure 3 . Three main stages may be distinguished chronologically.

1. Early gonadal autodifferentiation independent of pituitary differentiation which occurs later. - The sex of the gonad can be determined at 26 days by ultrastructural observation (Pelliniemi, 1975), and the future testis, but not the ovarian primordium, already contains testosterone (Raesides and Sigman, 1975). At 30 days, fetal sex can be determined by macroscopic observation of the gonad after dissection ; at 42 days the external genitals are differentiated (Patten, 1948).

Moreover, the work of Meusy-Dessolle (1974) and Colenbrander et al. (1978) shows that after a phase of very active testicular functioning $13 \mathrm{mg} / \mathrm{ml}$ of plasma testosterone at 55 days), fetal testosterone drops rapidly between 55 and 60 days and remains low until about 80 days, reflecting the appearance of testicular dependence on gonadotropins which are not detected in fetal blood until 80 days (Colenbrander et al., 1978).

Sexualization of the genital tract is due secondarily to early testosterone secretion.

2. Hypophysial gonadotrope autodifferentiation independent of $L H R H$ stimulus. - Five types of cells have been seen to differentiate in isolated early in vitro-cultured primordia of the pituitary (rats : Nemeskery et al., 1976 ; Watanabe and Daikoku, 1976 ; Begeot et al., 1979 ; birds : Ferrand et al., 1980). The same results were obtained after early encephalectomy in utero in rat (Chatelain et al., 1976, 1979). Moreover, in human anencephalic fetuses, Begeot et al. (1978) and Dubois et al. (1978) observed the onset of corticotrope differentiation.

Gonadotropes differentiate in the pig at $\mathbf{4 5}$ days, well before the LHRH fibers reach the median eminence (between 50 and 60 days) and the capillary loops of the portal system are established (between 60 and 70 days).

3. Hypothalamic assumption of reproductive system control. - The establishment of relations between hypothalamic and hypophysial cells (between 60 and 70 days) triggers the hypothalamo-pituitary-gonad system, as shown by increases in plasma LH (Elsaesser et al., 1976; Colenbrander et al., 1977 ; MacDonald et al., 1979) and plasma testosterone (Meusy-Dessolle, 1974 ; Colenbrander et al., 1978) beginning at 80 days.

Thus, it is our opinion that although LHRH does not induce gonadotrope differentiation, it is probably requisite to the acquisition of complete cell maturation and to good cell functioning. 
Acknowledgements. - The authors wish to thank C. Thibault, J. Barry, M. C. Levasseur, N. Meusy-Dessolle, P. C. Léglise and D. C. Dang for their advice, encouragement and precious material aid. This work was supported by DGRST contract $N^{\circ} 80.7 .0357$.

Résumé. Une étude immunocytologique de l'hypophyse de fœtus de porc domestique (Sus scrofa) a été réalisée à l'aide de quinze antisérum dirigés contre la plupart des hormones présentes dans l'adénohypophyse, afin de déterminer la séquence d'apparition des ćinq types de cellule endocrine de cet organe au cours du développement fœtal. Les premières hormones identifiées sont, à 33 jours, l'ACTH, la $\beta$-MSH, la $\beta$ - et $\gamma$-LPH et l' $\alpha$ - et $\beta$-endorphine ; l' $\alpha$-MSH apparaît à 40 jours et la STH à 45 jours. Entre 45 et 60 jours les hormones glycoprotéiques LH (45 jours), TSH (50 jours) et FSH (60 jours) apparaissent. La densité et l'intensité du marquage des cellules gonadotropes augmentent jusqu'à 80 jours date à laquelle elles atteignent des valeurs voisines de celles observées chez l'adulte. La prolactine n'a été observée qu'à partir de 80 jours.

Un antisérum anti-LHRH a été utilisé pour l'étude de la différenciation des neurones à LHRH dans I'hypothalamus entre 30 et 70 jours de la gestation. Les premiers péricaryons immunoréactifs ont été trouvés à 40 jours mais les fibres immunoréactives n'atteignent l'éminence médiane que vers 60 jours. Cependant nous n'avons observé de boucles capillaires bien différenciées qu'à partir de 70 jours.

Ces résultats, comparés à ceux obtenus sur la différenciation de la fonction de reproduction chez le fœtus de porc, permettent de dresser un schéma général, dans l'espèce porcine, de la différenciation et du fonctionnement du complexe neuroendocrine hypothalamo-hypophyso-gonadique au cours de la vie foetale. Ce schéma comprend : (i) autodifférenciation et autofonctionnement précoce de la gonade, (ii) autodifférenciation des cellules gonadotropes hypophysaires avec (iii) une prise en charge ultérieure par l'hypothalamus, suivie par une phase durant laquelle l'ensemble du système reproducteur fœtal fonctionne.

\section{Références}

ATINMO T., BAL DIJAO C., POND W. G., BARNES R. H., 1976. Decreased dietary protein or energy intake and plasma growth hormone levels of the pregnant pig, its foetuses and developing progeny. J. Nutr., 106, 940-946.

BAKER B. L., JAFFE R. B., 1975. The genesis of cell types in the adenohypophysis of the human fetus as observed with immunocytochemistry. Am. J. Anat., 143, 137-162.

BAKER B. L., YU Y. Y., 1977. An immunocytochemical study of human pituitary mammotropes from fetal life to old age. Am. J. Anat., 148, 217-240.

BARRY J., 1979. Immunohistochemistry of luteinising hormone-releasing hormone-producing neurons of the vertebrates. Int. Rev. Cytol., 60, 179-221.

BARRY J., DUBOIS M. P., 1974a. Etude comparée en immunofluorescence des neurones élaborateurs de LRF chez les mammifères. Arch. Anat. micr. Morph. exp., 63, 363-374.

BARRY J., DUBOIS M. P., 1974b. Etude en immunofluorescence de la différenciation prénatale des cellules hypothalamiques élaboratrices de LH-RF et de la maturation de la voie neurosécrétrice préoptico-infundibulaire chez le cobaye. Brain Res., 67, 103-113.

BARRY J., DUBOIS M. P., 1975. Immunofluorescence study of LRF producing-neurons in the cat and the dog. Neuroendocrinology, 18, 290-298.

BARRY J., DUBOIS M. P., POULAIN P., 1973. LRF-producing cells of the mammalian hypothalamus. Z. Zellforsch., 146, 351-366.

BARRY J., GIROD C., DUBOIS M. P., 1975. Topographie des neurones élaborateurs de LRF chez les primates. Bull. Assoc. Anat., 59, 103-110.

BEGEOT M., DUBOIS M. P., DUBOIS P. M., 1978. Immunologic localization of $\alpha$ and $\beta$-endorphin and $\beta$-lipotropin in corticotropic cells of the normal and anencephalic foetal pituitaries. Cell Tiss. Res., 193, 413-422. 
BEGEOT M., DUBOIS M. P., DUBOIS P. M., 1979. Influence de I'hypothalamus sur la différenciation des cellules présentant une immuno réactivité de type ACTH, $\beta \mathrm{LPH}$ ( $\beta$-Lipotropine), $\alpha$ et $\beta$ endorphine dans les ébauches antéhypophysaires de foetus de rat en culture organotypique. J. Physiol. Paris, 75, 27-31.

BUGNON C., BLOCH B., FELLMANN D., 1976a. Mise en évidence cyto-immunologique de neurones à LHRH chez le fœetus humain. C. R. Acad. Sci. Paris, Sér. D, 282, 1625-1627.

BUGNON C., BLOCH B., FELLMANN D., 1976b. Etude immunocytologique des cellules et des fibres à LHRH chez le fœetus humain. Bull. Assoc. Anat., 60, 269-278.

BUGNON C., LENYS D., BLOCH B., FELLMANN D., 1976c. Exploration cyto-immunologique sur coupes semi-fines des phénomènes de différenciation précoce de diverses populations cellulaires dans l'adénohypophyse fœtale humaine. C. R. Soc. Biol., 170. 975-982.

BUGNON C., BLOCH B., FELLMANN D., 1976d. Etudes cyto-immunologiques des cellules gonadotropes du fœtus humain. Bull. Ass. Anat., 169, 259-268.

BUGNON C., BLOCH B., FELLMANN D., 1977a. Etude immuno-cytologique des neurones hypothalamiques à LHRH chez le fœutus humain. Brain Res., 128, 249-262.

BUGNON C., BLOCH B., LENYS D., FELLMANN D., 1977b. Ultrastructural study of the LHRHcontaining neurons in the human fetus. Brain Res., 137, 175-180.

BUGNON C., BLOCH B., LENYS D., FELLMANN D., 1978. Cytoimmunological study of the LHRH neurons in humans during fetal life, 183-196. In Brain-endocrine interaction. III. Neural hormones and reproduction, 3rd int. Symp., Würzburg, 1977. Karger, Basel.

CHATELAIN A., DUBOIS M. P., DUPOUY J. P., 1976. Hypothalamus and cytodifferentiation of the fetal pituitary gland. Study in vivo. Cell Tiss. Res., 169, 335-344.

CHATELAIN A., DUPOUY J. P., DUBOIS M. P., 1979. Ontogenesis of the cells with polypeptidic hormones (ACTH, MSH, LPH, GH, prolactin) in the foetal hypophysis of the rat. Influence of the hypothalamus. Cell Tiss. Res., 196, 409-427.

CHRÉTIEN M., BENJANNET S., GOSSARD F., GIANOULAKIS C., CRINE P., LIS M., SEIDAH N. G., 1979. From $\beta$-lipotropin to $\beta$-endorphin and " pro opio-melanocortin ". Can. J. Biochem., 57, 1111-1121.

COLENBRANDER B., KRUIP Th. A. M., DIELEMAN S. J., WENSING C. J. S., 1977. Changes in serum LH concentrations during normal and abnormal sexual development in the pig. Biol. Reprod., 17, 506-513.

COLENBRANDER B., DE JONG F. H., WENSING C. J. G., 1978. Changes in serum testosterone concentrations in the male pig during development. J. Reprod. Fert., 53, 377-380.

DACHEUX F., 1978. Ultrastructural localization of gonadotrophic hormones in the porcine pituitary using the immunoperoxidase technique. Cell Tiss. Res., 191, 219-232.

DACHEUX F., 1981. Ultrastructural localization of corticotropin, $\beta$-lipotropin and $\beta$-endorphin in the porcine anterior pituitary. Cell Tiss. Res., 215, 87-101.

DACHEUX F., DUBOIS M. P., 1976. Ultrastructural localization of prolactin, growth hormone and luteinizing hormone by immunocytochemical techniques in bovine pituitary. Cell Tiss. Res., 174, 245-260.

DANCHIN E., DANG D. C., DUBOIS M. P., 1981. An immuno-cytological study of the adult crabeating macaque pituitary and its cytological differentiation during fetal life. Reprod. Nutr. Develop., 21, 441-454.

DUBOIS M. P., 1969. Cytologie de l'hypophyse des bovins : séparation des cellules somatotropes et des cellules à prolactine par immunofluorescence. Identification des cellules $\mathrm{LH}$ dans la pars tuberalis et la pars intermedia. Bull. Ass. Anat., 145, 139-146.

DUBOIS M. P., 1977. Sur les sécrétions hormonales polypeptidiques du complexe mère fœetus au $30^{\circ}$ jour de la gestation dans l'espèce porcine « In application des techniques immunologiques et immunocytologiques à l'étude de la différenciation cellulaire ". Bull. Soc. Zool. France, 102, suppl. 1, 63-70.

DUBOIS M. P., BARRY J., 1974. Répartition comparée de trois neuro facteurs hypothalamiques : LHRF, SRIF et neurophysine dans l'hypothalamus et l'éminence médiane : étude en immunofluorescence. Ann. Endocrinol., 35, 663-664.

DUBOIS M. P., MAULÉON P., 1969. Mise en évidence par immunofluorescence des cellules à activité LH dans I'hypophyse du fœtus de brebis. C. R. Acad. Sci. Paris, Sér. D, 269, 219222. 
DUBOIS P. M., BEGEOT M., DUBOIS M. P., 1975. Dissociation entre les sous-unités $\alpha$ et $\beta$ de LH dans l'antéhypophyse fœtale humaine. Ann. Endocr. Paris, 36, 321-322.

DUBOIS P. M., BEGEOT M. P., HERBERT D. C., 1978. Immunocytological localization of LH, $\mathrm{FSH}, \mathrm{TSH}$ and their subunits in the pituitary of normal and anencephalic human foetus. Cell Tiss. Res., 191, 249-265.

DUPOUY J. P., DUBOIS M. P., 1975. Ontogenesis of the $\alpha-M S H, \beta-M S H$ and ACTH cells in the foetal hypophysis of the rat. Correlation with the growth of the adrenals and adrenocortical activity. Cell Tiss. Res., 161, 373-384.

ELSAESSER F., ELLENDORFF F., POMERANTZ D. K., PARVIZI N., SMIDT D., 1976. Plasma levels of luteinising hormone, progesterone, testosterone and $5 \alpha$-dihydrotestosterone in male and female pigs during sexual maturation. J. Endocrinol., 68, 347-348.

FERRAND R., FREMONT P. H., DUBOIS M. P., 1980. Immunocytological study of the differentiation of grafted or in vitro-cultivated chick and quail adenohypophysis epithelial rudiment : evidence for polypeptidic hormones. Am. J. Anat., 158, 411-431.

FOLLENIUS E., DUBOIS M. P., 1978. Immunocytological detection and localization of a peptide reacting with an $\alpha$-endorphin antiserum in the corticotropic and melanotropic cells on the trout pituitary (Sa/mo irideux Gibb). Cell Tiss. Res., 188, 273-283.

GIROD C., DUBOIS M. P., 1976. Immunofluorescent identification of somatotropic and prolactin cells in the anterior lobe of the hypophysis (par distalis) of the monkey, Macacus irus. Cell Tiss. Res., 172, 145-148.

GROSS D. S., BAKER B. L., 1979. Developmental correlation between hypothalamic gonadotropin-realeasing hormone and hypophysial luteinizing hormone. Am. J. Anat., 154, 1-10.

HAKANSON R., EKMAN R., SUNDLER F., NILSSON R., 1980. A novel fragment of the cortico- $\beta$ lipotropin precursor. Nature, 283, 789-792.

HOFFMAN G. E., MELNYK V., HAYES T., BENNETT-CLARKE C., FOWLER E., 1978. Immunocytology of LHRH neurons, 67-82. In Brain-endocrine interaction. III. Neural hormones and reproduction, 3rd int. Symp., Würzburg, 1977. Karger, Basel.

IBATA Y., WATANABE K., KINOSHITA H., KUBO S., SANO Y., 1979. The location of LHRH neurons in the rat hypothalamus and their pathways to the median eminence. Cell Tiss. Res., 198, 381-395.

JENNES L., STUMPF W. E., 1980. LHRH systems in the brain of the golden hamster. Cell Tiss. Res., 209, 239-256.

JOST A., COHEN A., 1966. Signification de l'atrophie des surrénales fœtales du rat provoquée par I'hypophysectomie (décapitation). Dévelop. Biol., 14, 154-168.

JOST A., DUPOUY J. P., MONCHAMP A., 1966. Fonction corticotrope de I'hypophysé et hypothalamus chez le foetus de rat. C. R. Acad. Sci. Paris, Sér. D, 262, 147-150.

LEONARDELLI J., BARRY J., DUBOIS M. P., 1973. Mise en évidence par immunofluorescence d'un constituant immunologiquement apparenté au LH-RF dans I'hypothalamus et l'éminence médiane chez les mammifères. C. R. Acad. Sci. Paris, Sér. D, 276, 2043-2046.

LIWSKA, J., 1975. Development of the adenohypophysis in the embryo of the domestic pig. Folia morphol., 34, 211-217.

MACDONALD A. A., 1979. Patterns of endocrine change in the pig foetus. Anim. Reprod. Sci., 2, 289-304.

MACDONALD A. A., ELSAESSER F., PARVIZI N., HEILHECKER A., SMIDT D., ELLENDORFF F., 1979. Progesterone, oestradiol-17 $\beta$ and luteinising hormone concentrations in the blood and amniotic fluid of chronically catheterised pig foetus. J. Endocrinol., 80, 14 p.

MAINS R. E., EIPPER B. A., LING N., 1977. Common precursor to corticotropins and endorphins. Proc. nat. Acad. Sci., USA, 74, 3014-3018.

MELAMPY R. M., HENRICKS D. M., ANDERSON L. L., CHEN C. L., SCHULTZ J. R., 1966. Pituitary follicle-stimulating hormone and luteinising hormone concentrations in pregnant and lactating pigs. Endocrinology, 78, 801-804.

MEUSY-DESSOLLE N., 1974. Evolution du taux de testosterone plasmatique au cours de la vie fœtale chez le porc domestique (Sus scrofa L.). C. R. Acad. Sci. Paris, Sér. D, 278, 12571260.

MORICEAU-HAY D., DOERR-SCHOTT J., DUBOIS M. P., 1979. Mise en évidence par immuno- 
fluorescence des cellules à prolactine et des cellules somatotropes dans l'hypophyse du tétard de Xénope (Xenopus Laevis D.). Gen. comp. Endocrinol., 39. 322-326.

NAIK D. V., 1975a. Immuno-electron microscopic localization of luteinizing hormone-releasing ' hormone in the arcuate nuclei and median eminence of the rat. Cell Tiss. Res., 157, 437-455.

NAIK D. V., 1975b. Immunoreactive LHRH neurons in the hypothalamus identified by light and fluorescent microscopy. Cell Tiss. Res., 157, 437-455.

NEMESKERY A., NEMETH A., SETALO G., VIGH S., HALAZ B., 1976. Cell differentiation of the fetal rat anterior pituitary in vitro. Cell. Tiss. Res., 170, 263-273.

PATTEN B. M., 1948. Embryology of the pig. P. Blakiston's son and Com. Philadelphia and Toronto, $3^{\mathrm{e}} \mathrm{Ed}$.

PAULIN C., DUBOIS M. P., BARRY J., DUBOIS P. M., 1977. Immunofluorescence study of LHRH-producing cells in the human foetal hypothalamus. Cell Tiss. Res., 182, 341-345.

PELLINIEMI L. J., 1975. Ultrastructure of the early ovary and tesis in pig embryos. Am. J. Anat., 144. 89-112.

RAESIDES J. I., SIGMAN D. M., 1975. Testosterone levels in early fetal testes of domestic pigs. Biol. Reprod., 13, 318-321.

SETALO G., NAKANE P. K., 1976. Functional differentiation of the foetal anterior pituitary cells in the rat. Endocrinol. exp., 10, 155-166.

SETALO G., VIGH S., SCHALLY A. V., ARIMURA A., FLERKO B., 1976a. Changing immunoreactivity of the $\mathrm{LHRH}$-containing nerve terminals in the organum vasculosum of the lamina terminalis. Acta biol. Acad. Sci., Hung., 27, 75-77.

SETALO G., VIGH S., SCHALLY A. V., ARIMURA A., 1976b. Immunohistological study of the origin of LHRH-containing nerve fibers of the rat hypothalamus. Brain Res., 103, 597-602.

SILVERMAN A. J., 1976. Distribution of luteinizing hormone-releasing hormone $(\mathrm{LH}-\mathrm{RH})$ in the guinea pig brain. Endocrinology, 99, 30-41.

SMITH P. F., DORTZBACH C., 1929. The first appearance in the anterior pituitary of the developing pig foebus of detectable amounts of hormones stimulating ovarian maturity and general body browth. Anat. Rec., 43, 277-297.

STRYKER J. L., DZIUK P. J., 1975. Effects of fetal decapitation on fetal development, parturition and lactation in pigs. J. anim. Sci., 40, 282-287.

TRAMU G., DUBOIS M. P., 1972. Identification par immunofluorescence des cellules à activité LH du cobaye mâle. C. R. Acad. Sci. Paris, Sér. D, 275, 1159-1161.

TRAMU G., LEONARDELLI J., DUBOIS M. P., 1977. Immunohistochemical evidence for an ACTHlike substance in hypothalamic LHRH neurons. Neurosc. Lett., 6, 305-309.

WATANABE Y. C., DAIKOKU S., 1976. Immunohistochemical study on adenohypophysial primordia in organ culture. Cell Tiss. Res., 166, 407-412.

WATANABE Y. G., DAIKOKU S., 1979. An immunohistochemical study on the cytogenesis of adenohypophysial cells in fetal rats. Develop. Biol., 68, 557-567.

WEINDL A., SOFRONIEW M. V., 1978. Patterns of distribution of neurohormone in the mamalian brain, 117. In Brain-endocrine interaction. III. Neural Hormon. Reproduction, 3rd int. Symp., Würzburg, Karger, Basel.

WINTERS A. J., ROBERT L. E., PORTER J. C., 1974. Concentration and distribution of TRH and LHRH in the human fetal brain. J. clin. Endocrinol. Metab., 39, 960-963. 